\title{
The Impact of Mobile Digital Game in Learning Arabic Language at Tertiary Level
}

\author{
Mohammad Taufiq Abdul Ghani \\ Universiti Pendidikan Sultan Idris, Malaysia \\ ORCID: 0000-0003-3552-8828 \\ Mahizer Hamzah \\ Universiti Pendidikan Sultan Idris, Malaysia \\ ORCID: 0000-0003-3108-3913 \\ Wan Ab Aziz Wan Daud \\ Universiti Malaysia Kelantan, Malaysia \\ ORCID: 0000-0002-9507-5608 \\ Taj Rijal Muhamad Romli \\ Universiti Pendidikan Sultan Idris, Malaysia \\ ORCID: 0000-0003-0621-124X
}

Received: 28 May 2021

Accepted: 19 Oct 2021

\begin{abstract}
In the $21^{\text {st }}$ century, the advancement of technology has changed how people, especially the younger generation communicate and socialise with each other, as well as how they learn, acquire and process information. Therefore, this study aims to explore the impact on the employment of digital game-based learning in Arabic class at the tertiary level. This study is a qualitative study and data obtained through semi-structured interview sessions with 16 students at tertiary level, who exposed to the mobile digital game in learning the Arabic language. The students were chosen purposively based on several determining characteristics. The major findings indicated that the mobile digital game produces a significant effect on their learning achievement and enhances their Arabic vocabulary acquisition. Besides, the digital game-based learning also promotes a student-centred and interactive learning, while additionally creates an enjoyable environment for learning that could encourage student participation in class activities, sustain their learning engagement, and improve their motivation. This study explored opportunities for Arabic language lecturers to practice digital game-based learning as it promotes studentcentred learning, which would enhance student's participation in language activities and provide them with a joyful, fun, and active learning environment.
\end{abstract}

Keywords: Arabic language, mobile digital game, digital game-based learning, teaching and learning, mobile learning

\section{INTRODUCTION}

Second and foreign language students need to acquire at least 2000 vocabularies in high frequency in order to get at least an $80 \%$ understanding of the texts read. A collection of 2000 vocabulary is a realistic amount for students to understand the texts or communicate for the purpose of higher learning stages (Abdul Razif \& Mohd Zaki, 2017; Nation, 2001; Schmitt, 2000; Zainur Rijal \& Rosni, 2018). Thus, digital game-based 
learning has great potential in helping students enrich their vocabulary size in an interactive way. Previous studies have suggested that the employment of game-based learning could enhance student's achievement and motivation in learning new vocabulary. Digital game-based learning is one of the educational approaches that have a positive impact on students and can improve their knowledge of the embedded subject matter, increase the feeling of enjoyment, engagement, and interest during the learning process (Alessi \& Trollip, 1984; Amna et al., 2017; Baid \& Lambert, 2010; Chu \& Hung, 2015; Hamizul \& Nik Mohd Rahimi, 2015; Kirikkaya et al., 2010; Li \& Tsai, 2013; Muhammad Sabri, 2011; Papastergiou, 2009; Siti Nazleen \& Zuliana, 2017; Wilfried et al., 2014). It is suitable to be exploited as a learning tool that promotes a new learning environment for schools and universities.

A study revealed that educational games could develop students' thinking skills, increase the feeling of enjoyment while learning, and stimulate active learning rather than feeling burdened by the delivered information given by teachers (Abu Riya, 2001; Alessi \& Trollip, 1984; Amna et al., 2017; Baid \& Lambert, 2010; Chu \& Hung, 2015; Hamzul \& Nik Mohd Rahimi, 2015; Kirikkaya et al., 2010; Li \& Tsai, 2013; Muhammad Sabri, 2011; Norfaezah, 2019; Siti Nazleen \& Zuliana, 2017; Wilfried et al., 2014). Moreover, through gamebased learning, students are encouraged to try a new thing and not to be afraid of failing (Lee \& Hammer, 2011). It is a great tool that could improve learning skills, develop a positive attitude towards learning, and reduce the amount of stress accompanying the traditional learning process (Najdi \& Shiekh, 2012; Samir \& Randa, 2012). The digital game has become a creative, innovative, and dynamic educational tool that has attracted the full attention of schools and higher learning institutions. The digital game has a successful combination of multimedia learning (Mayer, 2021), which helps students memorise vocabulary meanings, pronunciations of a second or foreign language and enhances learning outcomes (Amna et al., 2017; Kalyuga et al., 2013; Tsai, 2017; Ugyen et al., 2015; Wilfried et al., 2014).

Although digital game-based learning is still in its infancy stage in learning the Arabic language, it is gaining more interest among researchers (Hamizul \& Nik Mohd Rahimi, 2015; Muhammad Sabri, 2011). Slowly, it has emerged as a significant focus among researchers due to the advancement of technologies in Malaysia compared to past decades. Digital game-based learning has become a new tool, approach, and strategy in language learning and teaching. Besides, it also has the potential to offer active learning, develop thinking skills, and provide an interactive platform for second or foreign language acquisition. Therefore, this study aims to explore the impact on the mobile digital game in the Arabic language class among Malaysian students at the tertiary level.

\section{LITERATURE REVIEW}

The current Arabic language teaching and learning process is still practised using the teacher-centred approach, characterised by the use of a whiteboard to explain lessons to students, and most of the lecturers only use a dictionary, direct translations, and memorisation strategies (Alhashemi \& Mahmoud, 2012; Mohamad Khaidir et al., 2020; Muhammad Sabri, 2011; Nik Hanan \& Rabiatul Aribah, 2014; Nur Naimah Akmar \& Harun, 2017; Nur Najhah Akmar \& Muhammad Sabri, 2020; Rosni, 2009). However, these strategies do not give the opportunity for students to learn and demotivate them from learning the Arabic language when they are unable to memorise the vocabulary. Besides, these factors will lead the students to attend Arabic classes only for the purpose of passing examinations. The learning-exam oriented system does not give the students an opportunity to master the language (Janudin, 2017; Norfaezah, 2019).

Many studies found that Malaysian students only have a moderate Arabic vocabulary size which does not reach a satisfactory level (Abdul Razif et al., 2016; Hasnurol, 2010; Izzah Syakirah \& Rosni, 2020; Saifudin, 2002; Siti Aisyah \& Zamri, 2016; Zainur Rijal et al., 2016). Among the major causes of this status might be due to the practice of traditional strategies in teaching that reduce the excitement factor and lead to low motivation and lack of enjoyment in the Arabic classes. Therefore, in order to improve the learning environment, students should be taught in a more interactive way (Ghazali et al., 2021; Hou et al., 2020; Zaid Arafat et al., 2016) and exposed to electronic materials for self-learning practices (Rosni, 2017); thus, developing excitement and enjoyment in the Arabic classroom. 
In this era of globalisation, traditional approaches to language teaching and learning have been challenged by new innovative approaches based on the latest advances in technology. The vast resources and opportunities that computers and internet providers have brought new tools, approaches, and language teaching and learning strategies (Gonulal, 2019). In the past two decades, improvement in technology has expanded the possibilities of the teaching and learning process, especially for the Arabic language. The mobile digital game is an effective tool that has good potential in helping digital native in learning purposes (Noor Azli et al., 2019). It has been recognised as an excellent learning tool to motivate students to participate in teaching and learning activities actively as well as develop positive perception and attitude (Alessi \& Trollip, 1984; Amna et al., 2017; Azman et al., 2018; Baid \& Lambert, 2010; Chu \& Hung, 2015; Hamadallah et al., 2019; Hamizul \& Nik Mohd Rahimi, 2015; Han \& Gwo, 2013; Insorio, 2021; Kirikkaya et al., 2010; Li \& Tsai, 2013; Muhammad Sabri, 2011; Siti Nazleen \& Zuliana, 2017; Wilfried et al., 2014). It could improve student's knowledge, develop enjoyment in the class environment, engage students throughout the learning process, and develop soft skills such as leadership and decision making (Hwang et al., 2012; Insorio, 2021; Lee \& Hammer, 2011; Muhideen et al., 2021; Najdi \& Sheikh, 2012; Paiva et al., 2016; Sung \& Hwang, 2013; Papastergiou, 2009; Yien et al., 2011).

Vocabulary is the main factor to master any language. The vocabulary size has a significant relationship with language skills. The bigger the vocabulary size, the better is the student's proficiency in language skills. In order to enrich students' vocabulary, an innovative learning strategy is needed, and the researcher believes that a digital game is one of the most appropriate vocabulary learning strategies to help the digital natives nowadays. Digital game-based learning gives opportunities for students to learn the Arabic vocabulary actively, participate in learning activities, develop thinking and decision-making skills, and improve students' motivation in Arabic language learning (Muhideen et al., 2021; Paiva et al., 2016).

\section{RESEARCH OBJECTIVE AND RESEARCH QUESTION}

The main objective of this study is to explore the impact of learning Arabic vocabulary through the mobile digital game at the tertiary level. Hence, the research question for this study: What are the impacts of the mobile digital game in learning Arabic vocabulary among tertiary students?

\section{METHODOLOGY}

\section{Sampling}

Students from four higher learning institutions in Peninsular Malaysia participated in this study which was selected from the northern, central, southern, and east coast regions. These institutions were selected through a cluster random sampling technique. This qualitative study was conducted by conducting semistructured interview sessions with 16 students at the tertiary level who were exposed to the mobile digital game for four weeks (four students from each higher learning institution). According to previous research, qualitative studies should have a minimum sample size of at least 12 to achieve data saturation (Fugard \& Potts, 2015; Braun \& Clarke, 2013; Guest et al., 2006). As a result, a sample size of 16 was deemed sufficient in this study to attain the saturation findings. According to Charmaz (2006), the researcher is able to stop collecting data when the categories or themes are saturated. In other words, after the researcher has gathered the data, there are no longer any new insights or properties revealed.

The students were chosen purposively based on several characteristics such as gender, language background, first language, and current year of study. The 16 students selected for the study comprised eight male and eight female students. Half of them have Arabic language background, while the remaining do not have Arabic language background. All of them are non-native Arabic speakers, and they are registered for the Elementary Arabic/ Arabic Level 1 course at their respective higher learning institutions. Table 1 demonstrates the student's demographic background. 
Table 1. Student's demographic background

\begin{tabular}{llcc}
\hline Item & Sub-item & Frequency (N) & Percentage (\%) \\
\hline Gender & Male & 8 & 50 \\
& Female & 8 & 50 \\
& Total & 16 & 100 \\
\hline Institution Region & Northern & 4 & 25 \\
& Central & 4 & 25 \\
& Southern & 4 & 25 \\
& East Coast & 4 & 25 \\
& Total & 16 & 100 \\
Arabic Language Background & Yes & 8 & 50 \\
& No & 8 & 50 \\
\hline
\end{tabular}

\section{Research Procedure}

This research procedure follows the ADDIE instructional design model phase.

\section{Analysis phase}

The first phase of developing the digital game involved reviewing the related literature to identify issues and problems in using education gems for language learning, specifically Arabic. After identifying the most potential problems, the researcher brainstormed on how the use of a digital education game could be a feasible solution to overcome the problems. Prior to collecting data on-site, the researcher sought permission to conduct research activities from the administrators of the selected universities. The researcher performed content analysis from previous studies to identify the students' needs in using mobile digital games in language learning. The data obtained to ensure the mobile digital game meets the students' needs in learning Arabic language learning, as well as their desired game criteria and features.

\section{Design phase}

The design phase began with instructors applying the findings from the analysis phase to create an overview structure for delivering the lessons (Lawrence, 2016). This includes determining the instructional process, learning objectives, assessment methodologies, preparing and testing, designing material, collaborating with exam and subject matter experts, and determining the media type, length, and response. The following step is to create a storyboard for the idea and a prototype. It is critical to be explicit and systematic during the design phase in order to build a logical approach and recognise and assess techniques for accomplishing the goal. Educators must focus on certain components and execute them precisely. Educators must create strategies for graphic and technology design, implement educational policies based on anticipated behavioural consequences, create the user interface and experience, and improve the visual appearance (Bamrara, 2018). Development is the third step. The development process entails the production and structuring of the instructional materials that will be used during the supervision (Lawrence, 2016). The teacher utilises all design process data to produce and install planned curriculum materials, as well as to coordinate and implement numerous development modes. Following that, various tests are run to identify errors and optimise operation. Suggestions may be used to analyse and adjust the course to ensure it meets expectations. Once the curriculum content is established, educators will conduct a mandatory pilot test. This can be accomplished by the intended participant's engagement and practise of the course content. The pilot's comments would also be beneficial in identifying flaws and further enhancing the overall procedure prior to the actual execution.

\section{Development phase}

The development process entails the production and structuring of the instructional materials that will be used during the supervision (Lawrence, 2016). The teacher utilises all design process data to produce and install planned curriculum materials, as well as to coordinate and implement numerous development modes. 
Following that, various tests are run to identify errors and optimise operation. Suggestions may be used to analyse and adjust the course to ensure it meets expectations. Once the prototype is established, educators will conduct a mandatory pilot test. This can be accomplished by the intended participant's engagement and practise of the course content. The pilot's comments would also be beneficial in identifying flaws and further enhancing the overall procedure prior to the actual execution.

\section{Implementation phase}

After the development phase was completed, the researcher met with Arabic lecturers teaching the students in the respective universities. After a series of discussions, the researcher decided to divide the students into two groups, the treatment and control group. Students in the treatment group used the mobile digital game developed by the researcher to learn Arabic vocabulary. In this regard, the lecturers serve as facilitators throughout the treatment duration. The lecturers provided assistance to students who were facing issues in learning Arabic vocabulary through a mobile digital game. On the other hand, the students in the control group underwent the traditional Arabic vocabulary instruction where the lecturers teach the Arabic vocabulary through the usual methods, which are predominantly focused on chalk and talk and lectures. The experimental process was carried out for four weeks.

\section{Evaluation phase}

After the treatment session completed, several students were purposively selected to participate in the semistructured interviews. The semi-structured interview sessions were conducted in Malay through a focus group technique, which comprised of four students from the treatment group from each institution. The students were chosen purposively based on their gender and language background. Each interview session lasted about 45 to 60 minutes. The semi-structured interviews used standard basic questions, and several additional questions which emerged as the interviews progressed were included. The researcher also took field notes and made audio recordings of each interview session. The semi-structured interview process is aimed to examine the impact of the use of the mobile digital game in the Arabic language classroom based on their experiences and expectation.

\section{Data Collection}

The semi-structured interview sessions were conducted in the Malay language through the application of a focus group, which comprised four students from each institution. This interview lasted about 45 to 60 minutes for each session. The semi-structured interviews followed standard basic questions, but several additional questions emerged accordingly as the interviews progressed. Field notes were taken, and audio was recorded during each interview session.

\section{Data Analysis}

After the interview process was completed, the researchers started to analyse the information. The researchers began to organise and prepare the data for analysis, including transcribing the semi-structured interviews and typing up field notes. Then the researcher started to look at all the data to have an overview of the general ideas on what respondents said. The researcher also analysed the impression of the overall depth and credibility of the data. Next, the researchers started coding all the data through Atlas.ti8 software. Coding is the process of organising data by bracketing chunks and writing a word representing a category in the margins (Rossman \& Rallis, 2012). After the coding process was completed, the researchers started to generate the themes through the coding process. The themes are the ones that appear as significant findings from the semi-structured interview.

Before writing finding reports, the researcher ensured the validity and reliability of the findings. According to Creswell (2018), qualitative validity indicates that the researchers check for the findings' accuracy by employing absolute procedures. In contrast, qualitative reliability means that the researcher's approach is consistent across different researchers and projects. Therefore, the researchers performed a validity procedure as proposed by Creswell (2018). This study conducted a "member checking" validity procedure in 
order to determine the accuracy of the semi-structured interview findings by taking the report and themes back to respondents and determining whether these respondents feel that they are accurate. This procedure involves conducting a follow-up online interview with respondents and provided an opportunity for them to comments on findings. For finding reliability, the researcher conducted several steps, as suggested by Gibbs (2007). The researcher checked the transcript to ensure that it does not contain apparent mistakes made during transcription. The researcher also confirmed there is no drift in the definition of codes and a shift in the codes' meaning during the coding process. Besides, cross-check codes were conducted to reduce errors in the analysing process.

The final step is writing a final report. The findings were constructed to present in detail what the researcher had discovered from the semi-structured interviews. The researcher included quotes, dialogue, and varied narrative forms in reporting all the findings and summarised the semi-structured interviews' validation toward quantitative data.

\section{Ethical Consideration}

An individual interview consent form was given to each participant. After obtaining their consent, the interview schedule was arranged. To keep their identities confidential, only basic demographic background is revealed. For conformability, the analysis of the study was shared with the participants to ensure that interview data supported the findings.

\section{RESULTS AND FINDINGS}

The findings of the semi-structured interview sessions were divided into three main themes, which are pedagogy, individual, and game features. There are four sub-themes underlying pedagogy which include language acquisition, learning environment, learning achievement, and learning strategy. Meanwhile, individual themes had also emerged with three sub-themes which are perceived acceptance, soft skills, and user motivation. Lastly, the game features theme has three sub-themes, including game element, game principle, and multimedia element. Figure 1 illustrates the resulting network.

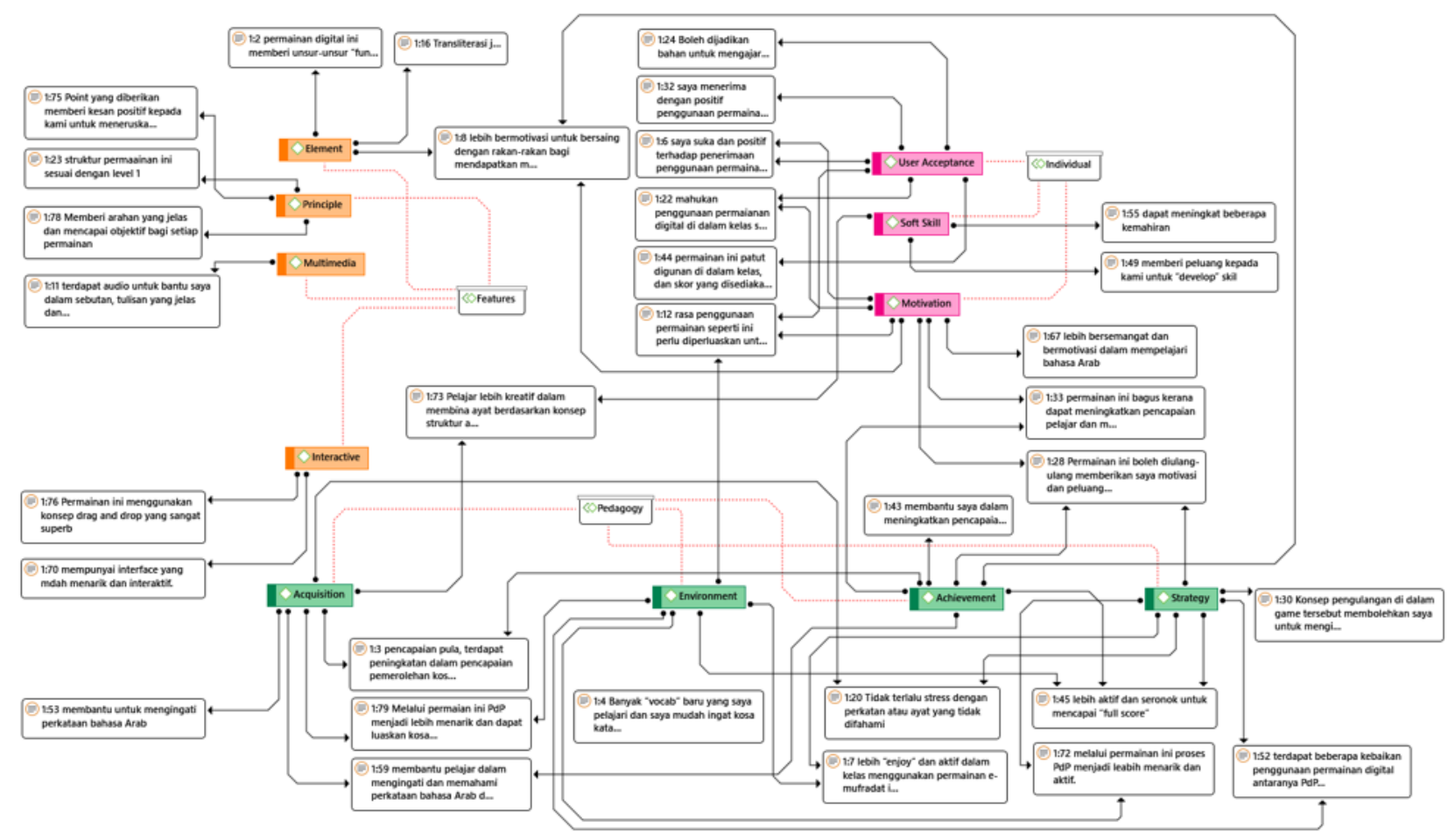

Figure 1. Result Network 
Theme 1: Pedagogy

\section{Acquisition}

A majority of the students agreed that there was an improvement in their Arabic vocabulary acquisition after using the mobile digital game. As mentioned by a student, “...melalui permainan ini, pembelajaran menjadi lebih menarik dan dapat meluaskan kosa kata bahasa Arab (...through this game, learning becomes more interesting and can expand Arabic vocabulary) (1:79)". They also said that "...terdapat peningkatan kosa kata bahasa Arab (...there is an increase in Arabic vocabulary) (1:3)". Besides, the results also found that the students were able to understand the vocabulary meaning in a simple sentence and also agreed that they were exposed to a lot of Arabic vocabulary and interactive learning as they mentioned that, "...permainan ini mempunyai ciri-ciri interaktif dan membantu kami untuk memahami makna perkataan dan menggunakannya di dalam ayat (...the game has interactive features and helps us to understand the meaning of words and use them in sentence) (1:16)". Therefore, the mobile digital game helped them in the vocabulary acquisition process. The students believed that the mobile digital game has helped to improve their vocabulary size. At the end of the intervention, they are able to construct a correct simple sentence using the vocabulary learned.

\section{Environment}

A majority of the students agreed that they had exposure to a new teaching and learning environment. The students were more active in class and the mobile digital game was able to develop a fun learning setting for them. The student expressed that, "...kelas lebih seronok dan aktif bila guna app ini (...class is more fun and active when using this app) (1:9)", and "...melalui permainan ni, proses pembelajaran menjadi lebih menarik dan aktif (...through this game, the learning process becomes more interesting and active) (1:91)". When the students said that, "...tidak terlalu stress dengan bila tidak faham maksud perkataan (... don't stress too much when we do not understand the meaning of the word) (1:62)", it demonstrated that the students were enjoying the process of learning Arabic and were contented through the use of the digital game. The digital game was also able to eliminate boredom and sleepiness symptom among them, and made students more active to achieve a full score for each game and level, and develop a competitive setting among them, as they quoted that, "...lebih bersemangat nak achieve full score nak compete dengan kawan (...more excited to achieve full score to compete with friends) (1:51)". In addition, this digital game had changed the domination of the use of textbooks, worksheets, and whiteboards. This was mentioned by a student, "...boleh ganti buku sebab content lebih kurang sama (...can replace the text book because the content is about the same) (1:135)". The perceived usefulness of this digital game can further benefit students as well as lecturers. They can practice the Arabic language outside of the classroom, compete among themselves at the hostels and are able to keep improving their scores.

\section{Achievement}

Based on the interview sessions, the results showed that the students agreed that they had an improvement in their score marks as they mentioned, "...game ni membantu saya dalam meningkatkan pencapaian saya dalam test yang diberikan (...this game helped me improve my achievement in test) (1:48)". They felt more active and developed a competitive mode among themselves to achieve a full score. A majority of the students experienced a positive impact on post-test results after learning through the application of the mobile digital game. Students without Arabic language background also had a good score. This was elaborated by a student without Arabic language background who remarked, "...game ini banyak membantu saya untuk achieve score yang baik walaupun ini kali pertama saya belajar bahasa Arab (...this game helped me achieve a good score even though this was my first time learning Arabic) (1:75)". The game template gave them an opportunity to improve their scores from time to time. This mobile digital game developed a challenging and competitive setting in the classroom among friends, and they were able to finish the tasks given within the stipulated time. This educational game has helped the students to practice the Arabic language in an interactive and fun environment. At the same time, they can enhance their knowledge, improve their scores, as well as enrich their vocabulary size. 


\section{Strategy}

The mobile digital game uses the concept of drill and practice which includes the repetition method. It gives the opportunity for students to improve their scores in a fun and tranquil classroom setting. The drill and practice in the mobile digital game helped them to improve their scores and vocabulary acquisition process as the student said, "...konsep permainan ini membolehkan saya untuk mengatur strategi nak achieve full score (...this game concept allows me to set the strategy to achieve full score) (1:30)" and "...lebih bersemangat nak achieve full score nak compete dengan kawan (...more excited to achieve full score to compete with friends) (1:51)". This strategy was imposed in the Arabic class to sustain students' engagement towards the digital game. The digital game was able to make the students more active and could experience the learning process fully. They enjoyed, played, and learned at the same time, and were able to eliminate anxiety among them especially among students without Arabic language background. This was remarked by a student who said, "...konsep game ni membolehkan saya untuk mengulang level game yang saya tak kuasai (...this game concept has allowed me to replay each game I did not master) (1:43)". The drill and practice strategy becomes a source of motivation for them to learn Arabic and sustains their engagement in class. This strategy also helps them to memorise the meanings and practice the functions of the vocabulary in a fun setting. It is also provided equal opportunities to all students to play until they achieve a better score, learn until they improve their confidence level towards the learning content, and achieve satisfaction with their own scores, learning gains, and vocabulary acquisition. The digital game had changed the teaching and learning session to be more interesting and effective.

\section{Theme 2: Individual}

\section{Perceived Acceptance}

The results of the interview demonstrated that a majority of the students had a positive attitude and preference to adapt to the digital game-based learning approach in their Arabic language classroom because the digital game was able to develop their motivation to continue the learning process. Quoting the students, "...saya suka dan postif terhadap penggunaan permainan ini di dalam kelas bahasa Arab (...I like and positive about using this game in Arabic class) (1:32)", and they also remarked that, "... saya mahukan penggunaan permainan seperti ini di dalam kelas (...I want to use this kind of game in the classroom) (1:22)". Some of them agreed that the content of the mobile digital game met their varying levels of competencies as they have a variety of Arabic language backgrounds. Moreover, they also realised that the learning contents are in line with their main reference as they said, "...boleh ganti buku sebab content lebih kurang sama (...can replace the book because the content is about the same) (1:135)". So, this will enhance their confidence and satisfaction towards the relevancy of the digital game. The students also suggested employing the digital game throughout the semester. Besides, the game score may be transferred as their quiz or assessment marks as they expressed that, "...permainan seperti ini patut digunakan di dalam kelas dan skor boleh dijadikan sebagai markah salah satu kuiz (...games like this should be used in class and scores can be used as the marks for one of the quizzes) (1:44)". As their preference and perception towards the digital game application differed, only some of them were comfortable and able to adapt the digital game approach in the Arabic class.

\section{Motivation}

The students agreed that, through the digital game approach, they have more enthusiasm to compete among themselves to achieve a full score for each game. Most of the students suggested continuing using the digital game in their Arabic language class because it was able to sustain their motivation to continue the learning process. They said that, "...lebih bersemangat dan bermotivasi untuk belajar bahasa Arab (...more excited and motivated to learn Arabic) (1:67)", and "...konsep permainan ini memberi motivasi untuk terus bermain hingga level terakhir (...the concept of the game motivates us to keep playing to the last level) (1:28)". The students also stated that the game scores and their achievements were also a boost factor to their motivation to study the Arabic language regardless of their Arabic language background. The mobile digital game also 
managed to stimulate the student's interest towards the Arabic language as well as the new approach in the classroom.

\section{Soft Skill}

The students agreed that, the mobile digital game was able to develop their soft skills such as strategy planning, decision making, higher order thinking skill, and language skills. The digital game was able to nurture student's creativity to construct a simple sentence based on the game concept exposure as they quoted that, "...permainan ini meningkatkan beberapa kemahiran seperti kemahiran mendengar dan membaca dan mampu untuk membina ayat ringkas (...the game improves some skills such as listening and reading skills and develop the ability to construct simple sentences) (1:55)".

\section{Theme 3: Game Features}

\section{Game element}

Through the analysis of the semi-structured interview sessions with students, the results demonstrated that the mobile digital game has a fun and enjoyment element which affected the learning environment and student behaviour in the Arabic class, as a student remarked that, "...game ini mempunyai unsur-unsur fun dan enjoy... (...this game has fun and enjoyable elements...) (1:2)". In addition, in order to meet the students' current need as they are learning the Arabic language at the Elementary level, this digital game provides them with a transliteration function which was able to assist them with the correct pronunciation of various words. This feature was well-supported by the students when they said that, "...fungsi transliterasi banyak bantu saya untuk menyebut perkataan bahasa Arab kerana saya tidak pernah belajar bahasa Arab sebelum ini (...transliteration function helped me to pronounce Arabic word because I had never learned Arabic before) (1:16)". Besides, this game also uses a drag and drop simple gameplay template to avoid heavy game storyline and enhance student's engagement in class. This digital game implements drill and practice instructional strategy which provided them with the opportunity to enhance their vocabulary acquisition through the repetition of vocabulary for each level.

\section{Game principle}

From the semi-structured interviews, the student said, "...struktur permainan ini sesuai dengan level 1 (...the structure of the game is suitable for level 1) (1:23)". Besides, they also said, "...point bagi jawapan yang betul membuat kami lebih bermotivasi untuk belajar (...rewards for the right answers make us more motivated to learn) (1:75)". These findings demonstrated that the mobile digital game's learning objectives met their knowledge and course levels. In fact, this digital game also provided them with rewards for their accomplishments and penalties for failures. This feedback was able to enhance students' engagement and motivate them to continue the learning process through continuing to play the game. Immediate and interactive feedback through visual and audio effect in the digital game provided them with a sense of control of their learning. They also said, "...game ni beri arahan yang jelas, dan memudahkan kami untuk bermain dan capai objektif yang diberikan (...the game gives us a clear instruction, and make it easier for us to play and achieve the objectives provided) (1:78)". In this regard, the mobile digital game provides clear instruction for each game and a clear target to be achieved as they expressed. This will help students to refine and focus their aim for each game and level. Moreover, based on the need analysis process, the digital game poses an appropriate challenge which is suitable for the student's level of competencies so that they are able to complete the task and finish the level.

\section{Multimedia}

Based on the interview sessions, the multimedia elements, especially audio recording has highly contributed in assisting the students in enhancing their listening and speaking skills. The students expressed that, "...game ini mempunyai audio pronunciation yang dapat bantu saya untuk menyebut perkataan dengan betul. Selain itu game ini juga tulisan yang jelas dan mudah untuk dibaca serta interface yang simple dan menarik (...this game has audio pronunciation that can help me spell the word correctly. On top of that, the game also has 
clear font, easy-to-read writing and a simple and engaging interface) (1:11)". The digital game provides them with a simple and clear text to improve its clarity and helps ease their reading experience. Taking into account the student's language background, this feature will assist them to improve their Arabic literacy skill. Besides, in terms of the colours used, game layout and user interface, the digital game uses an appropriate range of colours to increase clarity by using a range of low contrast colours for the background and high contrasts colours for characters and gameplay elements. The game also provides a simple layout and locates the item at the same place for each page. This helps to improve the visible and invisible interactions between the game and the players.

\section{DISCUSSION AND IMPLICATION}

This study conducted semi-structured interview sessions with 16 tertiary students who were selected purposively to express their opinions after the intervention introduced using a mobile digital game in an Arabic language course. The study found that the students had an improvement in their achievement and an enhancement in their Arabic vocabulary acquisition after using the mobile digital game. Therefore, this study proves that digital game-based learning has a significant impact on students' achievement in learning the Arabic language. This result is also in line with previous empirical studies on the effectiveness of digital gamebased learning (Amna et al., 2017; Azman et al., 2018; Cardenas-Moncada et al., 2020; Chu \& Hung, 2015; Li \& Tsai, 2013; Roodt \& Ryklief, 2019; Tsai, 2017; Ugyen et al., 2015; Wilfried et al., 2014). In addition, the mobile digital game is able to treat the students equally regardless of their gender. Although gender preferences might differ, the effectiveness of this digital game could be provided equally. Several empirical studies support the qualitative findings of this study on gender differences (Lester et al., 2014; Papastergiou, 2009; Philip et al., 2015; Ugyen et al., 2015; Wilfried et al., 2014; Yang \& Chen, 2010; Yien et al., 2011). Besides, during the semi-structured interview sessions, a majority of the students expressed that they had experienced exposure to a new teaching and learning environment. The students were also more active in class (Alessi \& Trollip, 1984; Amna et al., 2017; Azman et al., 2018; Baid \& Lambert, 2010; Cardenas-Moncada et al., 2020; Cardinot, 2019; Chu \& Hung, 2015; Ghazali et al., 2021; Hamzul \& Nik Mohd Rahimi, 2015; Hou et al., 2020; Kirikkaya et al., 2010; Li \& Tsai, 2013; Sahrir, 2011; Siti Nazleen \& Zuliana, 2017; Wilfried et al., 2014), as the mobile digital game was able to develop a fun challenge and introduce freshness in their learning setting (Ibrahim et al., 2017; Papastergiou, 2009; Shin \& Shin, 2011; Siti Nazleen \& Zuliana, 2017; Yusoff, 2010). Students become more energetic and optimistic about achieving a full score for each game and level and develop a competitive setting among them. They enjoyed learning Arabic, and this learning setting was able to eliminate boredom and sleepiness symptoms among them. Moreover, they also expressed that learning through the mobile digital game is a good practice and strategy (Kayaoglu, 2013; Kuen, 2010; Nadhilah \& Kamarul Shukri, 2018; Park, 2010; Sueraya et al., 2012), in learning the Arabic language, especially for beginners (Amna et al., 2017; Azman et al., 2018; Fu, 2017; Ugyen et al., 2015; Wilfried et al., 2014).

Several embedded features in the mobile digital game assist them well in the learning process such as learning feedback, audio pronunciation and transliteration. The audio helps them with the pronunciation of the Arabic vocabulary while the transliteration feature is used to familiarise the students with Arabic vocabulary. Therefore, to facilitate the beginner students' learning experience, the digital game should vary in the approach and have a transliteration feature to help them improve their reading in Arabic vocabulary without emphasising on grammar (Ashinida, 2016). Besides, the game-based feedback provided utilised gaming principles by being brief so that it would encourage self-reflection (Chu \& Fowler, 2020). In addition, as argued by other studies, such a significant increase in students' vocabulary achievement could be influenced by the unique characteristics of the educational game, including elements of enjoyment and fun, challenging and the novelty of learning through a mobile digital game (Ibrahim et al., 2017; Insorio, 2021; Siti Nazleen \& Zuliana, 2017). In this study, the mobile digital game was designed in accordance with digital game principles and multimedia principles. Furthermore, several interactive customisations have been included to help students enrich their Arabic vocabulary knowledge. The digital game principles create a fun and enjoyable learning experience in Arabic class. At the same time, the students believe that the multimedia elements have helped them to learn better. Another attractive feature of the game is the provision of 
immediate and interactive feedback so that the users are able to check their scores immediately and compete with their friends in real-time. Lastly, the users were able to reach the learning goal in each game due to the simple and clear game flow. The finding of this study further proves the strong role played by the digital game is in encouraging learners to participate actively in the learning process (Akbar, 2020; Azman et al., 2018; Cardenas-Moncada et al., 2020; Merilainen, 2019; Roodt \& Ryklief, 2019; Siti Nazleen \& Zuliana, 2017).

The students also expressed their opinions on the mobile digital game as being able to eliminate anxiety among them, especially students without Arabic language background. As some of the students are first-time Arabic learners, they might feel burdened, experience anxiety, and these would demotivate their learning interests. However, the mobile digital game changes their learning perception towards the Arabic language. These findings are supported by previous works of literature on the effect of student's language background (Gebauer et al., 2013; Lazaruk, 2007; Vega, 2014). Digital game intrinsically motivates them to engage in the activity which can benefit learning (Akbar, 2020; Chang et al., 2017; Gonulal, 2019; Hamizul \& Nik Mohd Rahimi, 2015; Hao \& Lee, 2019; Huang \& Oh, 2018; Lee \& Hao, 2015; Lin et al., 2017; Lu et al., 2018; Merilainen, 2019; Shabalina et al., 2015; Travis, 2018; Wu, 2018), by developing a sense of competition with each other to achieve a full score in each game as well as develop and enhance their soft skills (Hwang et al., 2012; Lee \& Hammer, 2011; Najdi \& Sheikh, 2012; Paiva et al., 2016; Papastergiou, 2009; Sung \& Hwang, 2013; Yien et al., 2011), such as strategy planning, decision making, higher-order thinking skill as well as language skills.

Hence, based on the discussion above, the mobile digital game has helped the students in their learning and significantly improved the tertiary students' Arabic vocabulary knowledge. The students achieved a positive score in the game, which reflects their improvement of vocabulary acquisition. Empirically, the use of mobile digital games is deemed as the best method to improve the learning achievement of both male and female students. It is also suitable to be employed for students at the beginner level which has no Arabic language background. Digital game-based learning also provides an interactive environment learning that could improve student engagement and participation in-class activities. Besides, the use of digital games for learning provides intrinsic motivation for students to continue learning.

\section{CONCLUSIONS}

In regards to the discussion above, it can be concluded that the mobile digital game demonstrates a significant contribution to the learning of Arabic vocabulary among students at tertiary level. The students had excellent achievements in their scores and demonstrated an enhanced acquisition in their vocabulary. The mobile digital game is one of the best methods and practices that has been proven empirically to be effective based on previous studies and through the qualitative findings from this study, it equally affected both gender, male and female. In addition, it is also suitable to be employed at the beginner's level. The digital game-based learning promotes a student-centred and interactive environment for learning that could improve student's participation in class activities and sustain their learning engagement. Besides, the employment of digital game also intrinsically motivates them to continue with the learning process.

Numerous limitations apply to this study. The digital mobile game is only compatible with the Android operating system. However, because the majority of this research's participants use the Android operating system, conducting this study should be quite straightforward. Additionally, this study only does the intervention for four weeks. Despite the intervention's brief duration, it has a tremendous influence on students in a variety of ways. If the duration of the intervention is extended, the outcome will be improved. Thus, this study would like to advise for future research that a quantitative study be conducted using a quasiexperiment and inferential testing in order to determine the effectiveness of mobile digital games and their effect on student motivation and achievement.

Author contributions: All authors were involved in concept, design, collection of data, interpretation, writing, and critically revising the article. All authors approve final version of the article.

Funding: The authors received no financial support for the research and/or authorship of this article.

Declaration of interest: Authors declare no competing interest.

Data availability: Data generated or analysed during this study are available from the authors on request. 


\section{REFERENCES}

Abdul Razif, Z., \& Mohd Zaki, A. R. (2017). Arabic language vocabulary size and its relation with speaking skills. Jurnal Sultan Alauddin Sulaiman Shah, 4(1), 220-228.

Abdul Razif, Z., Saifulah, S., Khairil Ashraf, E., Mohd Zaki, A. R., Khirulnizam, A. R., Muhammad Haron, H., \& Naqibah, M. (2016). Pembelajaran kosa kata Arab berbantukan aplikasi [Application-assisted Arabic vocabulary learning]. IRSYAD2016, Selangor, Malaysia.

Abu Riya, M. (2001). The impact of using computerized games in the sixth grade students in acquiring the four arithmetic algorithms. Studies of Educational Sciences, 164-176.

Akbar, B. (2020). Mainstream theoretical trends and future directions of L2 motivation studies in classroom and CALL contexts. CALL_EJ, 2(1), 1-28.

Alessi, S. M., \& Trollip, S. R. (1984). Computer-based instruction: Methods and development (2nd ed.). Prentice-Hall.

Alhashemi, A., \& Mahmoud, A. (2012). Vocabulary learning strategies used by learners of Arabic as a foreign language in the University of Islamic Sciences in Malaysia and their beliefs about vocabulary. Journal of Educational Sciences, 8(2), 105-117.

Amna, K., Farzana, H. A., \& Muhammad Muddasir, M. (2017). Use of digital game based learning and gamification in secondary school science: The effect on student engagement, learning and gender difference. Education and Information Technologies, 22, 2767-2808. https://doi.org/10.1007/s10639-017-9622-1

Ashinida, A. (2016). A need analysis for the course materials design of the Arabic language course. International Journal of Social Science and Humanity, 6, 423-426. https://doi.org/10.7763/IJSSH.2016.V6.684

Azman, A. R., Muhammad Sabri, S., Nurkhamimi, Z., \& Khafidz, A. H. (2018). An evaluation of Global Zakat Game (GZG) as edutainment board game in enhancing Zakat education in Malaysia. Educational Research and Reviews, 13(5), 166-172. https://doi.org/10.5897/ERR2018.3487

Baid, H., \& Lambert, N. (2010). Enjoyable learning: The role of humour, games, and fun activities in nursing and midwifery education. Nurse Education Today, 30(6), 548-552. https://doi.org/10.1016/j.nedt.2009.11.007

Bamrara, A. (2018). Applying ADDIE model to evaluate faculty development program. Issues and Ideas in Education, 6(1), 11-28. https://doi.org/10.15415/iie.2018.61001

Braun, V., \& Clarke, V. (2013). Successful qualitative research: A practical guide for beginners (1st ed.). SAGE.

Cardenas-Moncada, C., Veliz-Campos, M., \& Veliz, L. (2020). Game-based student response system: The impact of Kahoot in a Chilean vocational higher education EFL classroom. CALL_EJ, 2(1), 64-78.

Cardinot, A. (2019). Game-based learning to engage students with Physics and Astronomy using a board game. International Journal of Gmae-Based Learning, 9(1), 42-57. https://doi.org/10.4018/IJGBL.2019010104

Chang, Y. -H., Hwang, J. -H., \& Fang, R. J. (2017). A kinetict-and game-based interactive learning system. EURASIA Journal of Mathematics Science and Technology Education, 13(2), 4897-4914. https://doi.org/10.12973/eurasia.2017.00972a 
Charmaz, K. (2006). Constructing grounded theory (2nd ed.). SAGE. https://doi.org/10.1002/9781405165518.wbeosg070

Chu, H.-C., \& Hung, C.-M. (2015). Effects of the digital game-development approach on elementary school student's learning motivation, problem solving, and learning achievement. International Journal of Distance Education Technologies, 13(1), 87-102. https://doi.org/10.4018/ijdet.2015010105

Chu, M.-W., \& Fowler, T. A. (2020). Gamification of formative feedback in language arts and mathematics classrooms: Application of the Learning Error and Formative Feedback (LEAFF) model. International Journal of Game-Based Learning, 10(1), 1-18. https://doi.org/10.4018/IJGBL.2020010101

Creswell, J. W., \& Creswell, J. D. (2018). Research design: Qualitative, quantitative, and mixed methods approaches (5th ed.). SAGE.

Fugard, A. J. B., \& Potts, H. W. W. (2015). Supporting thinking on sample sizes for thematic analyses: A quantitative tool. International Journal of Social Research Methodology, 18(6), 669-684. https://doi.org/10.1080/13645579.2015.1005453

Gebauer, S. K., Zaunbauer, A. C., \& Moller, J. (2013). Cross-language transfer in English immersion programs in Germany: Reading comprehension and reading fluency. Contemporary Educational Psychology, 38(1), 64-74. https://doi.org/10.1016/j.cedpsych.2012.09.002

Ghazali, Z., Siti Rosilawati, R., Noor Azli, M. M., Muhammad Sabri, S., \& Effendi, A. (2021). Teachers' perspective on digital game-based language learning for Arabic language in Malaysian primary schools. Advances in Social Science, Education and Humanities Research, 518, 436-441. https://doi.org/10.2991/assehr.k.210120.157

Gibbs, G. R. (2007). Analyzing qualitative data. In U. Flick (Ed.), The SAGE qualitative research kit. SAGE. https://doi.org/10.4135/9781849208574

Gonulal, T. (2019). The use of Instagram as a mobile-assisted language learning tool. Contemporary Educational Technology, 10(3), 309-323. https://doi.org/10.30935/cet.590108

Guest, G., Bunce, A., \& Johnson, L. (2006). How many interviews are enough?: An experiment with data saturation and variability. Field Methods, 18(1), 59-82. https://doi.org/10.1177/1525822X05279903

Hamadallah, M. S. K., Nik Mohd Rahimi, N. Y., Noor Saazai, M. S., Hazlina, A., \& Ashwaq, M. S. K. (2019). The effect of language games on smartphones in developing Arabic speaking skills among non-native speakers. Creative Education, 10, 972-979. https://doi.org/10.4236/ce.2019.105073

Hamizul, M., \& Nik Mohd Rahimi, N. Y. (2015). Design and development of Arabic online games: A conceptual paper. Procedia Social and Behavioral Sciences, 174, 1428-1433. https://doi.org/10.1016/j.sbspro.2015.01.771

Han, Y. S., \& Gwo, J. H. (2013). A collaborative game-based learning approach to improving students' learning performance in science courses. Computer \& Education, 63, 43-51. https://doi.org/10.1016/j.compedu.2012.11.019

Hao, K.-C., \& Lee, L.-C. (2019). The development and evaluation of an educational game integrating augmented reality, ARCS model, and types of games for English experiment learning: An analysis of

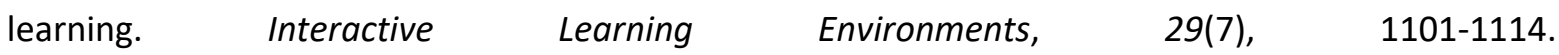
https://doi.org/10.1080/10494820.2019.1619590 
Hasnurol, H. (2010). Penguasaan kosa kata Arab program j-QAF dalam kalangan murid sekolah rendah [Arabic vocabulary mastery of the j-QAF program among primary school students] [Unpublished master thesis, Universiti Putra Malaysia].

Hou, X., Nguyen, H. A., Richey, J. E., \& McLaren, B. M. (2020). Exploring gender and enjoyment impact learning in a digital learning game. Artificial Intelligence in Education, 12163, 255-268. https://doi.org/10.1007/978-3-030-52237-7_21

Huang, W. D., \& Oh, E. G. (2018). Motivational support from Digital Game-Based Learning Environments (DGBLEs) for scientific topics designed by novice end users. Educational Media International, 55(2), 123-136. https://doi.org/10.1080/09523987.2018.1484043

Hwang, G.-J., Wu, P.-H., \& Chen, C.-C. (2012). An online game approach for improving students' learning performance in web-based problem-solving activities. Computers \& Education, 1246-1256. https://doi.org/10.1016/j.compedu.2012.05.009

Ibrahim, R., Masrom, S., Yusoff, R. M. C., Zainuddin, N. M. M., \& Rizman, Z. I. (2017). Student acceptance of educational games in higher education. Journal of Fundamental and Applied Sciences, 9(3S), 809-829. https://doi.org/10.4314/jfas.v9i3s.62

Insorio, A. O. (2021). Technological and operational mobile learning readiness of secondary teachers. International Journal of Pedagogical Development and Lifelong Learning, 2(1), ep2103. https://doi.org/10.30935/ijpdll/9362

Izzah Syakirah, M., \& Rosni, S. (2020). Arabic vocabulary translation skills level among Malaysian Higher Islamic Religious Certificate (STAM) students. Al-Qanatir International Journal of Islamic Studies, 72 85.

Janudin, S. (2017). Learning Arabic language via interactive mobile application. In International Carnival on e-Learning (pp. 361-363). Nilai, Malaysia.

Kalyuga, M., Mantai, L., \& Marrone, M. (2013). Efficient vocabulary learning through online activities. Procedia Social and Behavioral Sciences, 83, 35-38. https://doi.org/10.1016/j.sbspro.2013.06.007

Kayaoglu, M. N. (2013). Poor and good learner's language belief and their influence on their language learning strategy use. Novitas-ROYAL, 7(1), 36-54.

Kirikkaya, E. B., Iseri, S., \& Vurkaya, G. (2010). A board game about space and solar system for primary school students. The Turkish Online Journal of Educational Technology, 9(2), 1-13.

Kuen, Y. L. (2010). English learning strategies used by form six students in secondary schools [Unpublished master thesis, Universiti Kebangsaan Malaysia].

Lawrence, C. (2016). Using the ADDIE model of instructional design to teach chest radiograph interpretation. Journal of Biomedical Education, 2016, 9502572. https://doi.org/10.1155/2016/9502572

Lazaruk, W. (2007). Linguistic, academic, and cognitive benefitsof French immersion. Canadian Modern Language Review, 63(5), 605-627. https://doi.org/10.3138/cmlr.63.5.605

Lee, J., \& Hammer, J. (2011). Gamification in education: What, how, why bother? Academic Exchange Quartely, 15(2), 146.

Lee, L. -C., \& Hao, K. -C. (2015). Designing and evaluating digital game-based learning with the ARCS motivation model, humor, and animation. International Journal of Technology and Human Interaction, 11(2), 80-95. https://doi.org/10.4018/ijthi.2015040105 
Lester, J. C., Spires, H. A., Nietfeld, J. L., Minogue, J., Mott, B. W., \& Lobene, E. V. (2014). Designing gamebased learning environment for elementary science education: A narrative-centered learning perspective. Information Sciences, 264, 4-18. https://doi.org/10.1016/j.ins.2013.09.005

Li, M. -C., \& Tsai, C. -C. (2013). Game-based learning in science education: A review of relevant research. Journal of Science Education and Technology, 22(6), 877-898. https://doi.org/10.1007/s10956-0139436-x

Lin, C. -H., Huang, S. -H., Shih, J. -L., Alexandra, C., \& Gheorghita, G. (2017, July 3-7). Game-based learning effectiveness and motivation study between competitive and cooperative modes [Paper presentation]. 2017 IEEE 17th International Conference on Advanced Learning Technologies (ICALT), Timisoara, Romania. https://doi.org/10.1109/ICALT.2017.34

Lu, S. -J., Liu, Y. -C., Chen, P. -J., \& Hsieh, M. -R. (2018). Evaluation of AR embedded physical game on students' learning achievement and motivation on elementary natural science. Interactive Learning Environments, 28(4), 451-463. https://doi.org/10.1080/10494820.2018.1541908

Mayer, R. E. (2021). Multimedia learning (2nd ed.). Cambridge University.

Merilainen, M. (2019). First-timer learning experiences in global game jam. International Journal of GameBased Learning, 9(1), 30-41. https://doi.org/10.4018/IJGBL.2019010103

Mohamad Khaidir, S., Arifin, M., \& Mohamad Azrien, M. A. (2020). Vocabulary learning strategies between learners of Arabic major and non-Arabic major at a Malaysia public university. GESJ: Education Science and Psychology, 91-106.

Muhammad Sabri, S. (2011). Analysis, design and development of an online vocabulary game for Arabic elementary learners [PhD Thesis, Universiti Teknologi MARA].

Muhideen, S., Chu, J., Rufai, O. H., Shahani, R., \& Amosun, T. S. (2021). Rethinking communication and crowdsourced technology: Mediating role of mobile-learning tie to broadband. European Journal of Interactive Multimedia and Education, 2(1), e02106. https://doi.org/10.30935/ejimed/9703

Nadhilah, A. P., \& Kamarul Shukri M. T. (2018). Perbezaan jantina dalam penggunaan strategi pembelajaran kemahiran berbahasa Arab [Gender differences in the use of Arabic language skills learning $\begin{array}{lllll}\text { strategies]. Journal of Nusantara } & \text { Studies, }\end{array}$ https://doi.org/10.24200/jonus.vol3iss1pp143-153

Najdi, S., \& Sheikh, R. E. (2012). Educational games: Do they make a difference? Procedia - Social And Behavioral Sciences, 47, 48-51. https://doi.org/10.1016/j.sbspro.2012.06.612

Nation, I. S. (2001). Learning vocabulary in another language. Cambridge University Press. https://doi.org/10.1017/СBO9781139524759

Nik Hanan, N. M., \& Rabiatul Aribah, M. I. (2014). Arabic vocabulary learning strategies among non-native speakers: A case of IIUM. Global Journal of Al Thaqafah, 4(2), 125-133. https://doi.org/10.7187/GJAT722014.04.02

Noor Azli, M. M., Hafawati, I., Ghazali, Z., Siti Rosilawati, R., Muhammad Sabri, S., \& Harwati, H. (2019). Digital games based language learning for arabic literacy remedial. Creative Education, 10, 3213-3222. https://doi.org/10.4236/ce.2019.1012245

Norfaezah, M. H. (2019). Challenges in teaching and learning Arabic language in secondary school: Students', teachers', and parents' view. e-Bangi, 1-14. 
Nur Naimah Akmar, K., \& Harun, B. (2017). Strategi pembelajaran kosa kata dan penguasaan pengetahuan kosa kata Arab dalam kalangan pelajar STAM [Vocabulary learning strategies and mastery of Arabic vocabulary knowledge among STAM students]. Attarbawiy: Malaysian Online Journal of Education, 1(1), 64-73.

Nur Najhah Akmal, R., \& Muhammad Sabri, S. (2020). The effectiveness of thingLink in teaching new vocabulary to non-native beginners of the Arabic language. IIUM Journal of Educational Studies, 8(1), 32 - 52. https://doi.org/10.31436/ijes.v8i1.274

Paiva, A. C. R., Flores, N. H., Barbosa, A. G., \& Ribeiro, T. P. B. (2016). iLearnTest - framework for educational games. Procedia - Social And Behavioral Sciences, 228, 443-448. https://doi.org/10.1016/j.sbspro.2016.07.068

Papastergiou, M. (2009). Digital game-based learning in high school computer science education: Impact on educational effectiveness and etudent motivation. Computers \& Education, 52(1), 1-12. https://doi.org/10.1016/j.compedu.2008.06.004

Park, G. (2010). Investigation into learning strategies used by effective and less effective EFL learners in Korea. Asian Social Sciences, 8, 3-13. https://doi.org/10.5539/ass.v6n8p3

Roodt, S., \& Ryklief, Y. (2019). Using digital game-based learning to improve the academic efficiency of vocational education students. International Journal of Game-based learning, 9(4), 45-69. https://doi.org/10.4018/IJGBL.2019100104

Rosni, S. (2009). Isu pembelajaran bahasa Arab di Malaysia [Arabic language learning issues in Malaysia]. Universiti Sains Islam Malaysia.

Rosni, S. (December, 2017). Pembelajaran bahasa Arab perlukan perubahan [Learning Arabic needs change]. Universiti Sains Islam Malaysia. USIM News. https://www.usim.edu.my/news/in-ourwords/pembelajaran-bahasa-arab-perlu-perubahan/

Rossman, G. B., \& Rallis, S. F. (2012). Learning in the field: An introduction to qualitative research (3rd ed.). SAGE.

Saifudin, H. (2002). Penguasaan perbendaharaan kata bahasa Arab di kalangan pelajar pelajar tingkatan tiga: Satu kajian kes di Sekolah Menengah Kebangsaan (Agama) Negeri Melaka [Arabic vocabulary mastery among form three students: A case study in Melaka State National (Religious) Secondary School] [Unpublished M.A. dissertation, Universiti Malaya].

Samir, N., \& Randa E. S. (2012). Educational games: Do they make a difference? Procedia Social and Behavioral Sciences, 47, 48-51. https://doi.org/10.1016/j.sbspro.2012.06.612

Schmitt, N. (2000). Vocabulary in language teaching. TESOL Quaeterly, 36, 235. https://doi.org/10.2307/3588334

Shabalina, O., Mozelius, P, Vorobkalov, C., Malliarakis, C., \& Tomos, F. (2015, July 6-8). Creativity in digital pedagogy and game-based learning techniques: Theoretical aspects, techniques and case studies [Paper presentation]. 2015 6th International Conference on Information, Intelligence, Systems and Applications (IISA), Corfu, Greece. https://doi.org/10.1109/IISA.2015.7387963

Shin, D. H., \& Shin, Y. J. (2011). Why do people play social network games? Computers in Human Behavior, 27(2), 852-861. https://doi.org/10.1016/j.chb.2010.11.010

Siti Aisyah, I., \& Zamri, A. (2016). Saiz kosa kata bahasa Arab dan hubungannya dengan kemahiran menulis [Arabic vocabulary size and its relationship with writing skills] [Paper presentation]. Seminar 
Antarabangsa Pengajaran Bahasa dan Sastera Arab Kepada Penutur Bukan Arab [International Seminar on Teaching Arabic Language and Literature to Non-Arabic Speakers], Kelantan, Malaysia.

Siti Nazleen, A. R., \& Zuliana, T. (2017). The effect of digital game-based learning on primary school students' English vocabulary achievement and acceptance. Innovative Teaching and Learning Journal, 1(1), 6174.

Sueraya, C. H., Ismail, S. A., Arifin, M., \& Ismaiel Hassanien, A. M. (2012). Strategies to develop speaking skills among Malay learners of Arabic. International Journal of Humanities and Social Science, 2(17), 303310.

Sung, H.-Y., \& Hwang, G.-J. (2013). A collaborative game-based learning approach to improving students' learning performance in science cources. Computers \& Education, 63, 43-51. https://doi.org/10.1016/j.compedu.2012.11.019

Travis, N. T. (2018). Design case: Implementing gamification with ARCS to engage digital natives. Journal of Empowering Teaching Excellence, 2(1), 23-52.

Tsai, F.-H. (2017). An investigation of gender differences in a game-based learning environment with different game modes. EURASIA Journal of Mathematics Science and Technology Education, 13(7), 3209-3226. https://doi.org/10.12973/eurasia.2017.00713a

Ugyen, D., Patcharin, P., \& Niwat, S. (2015). Gender differences in students' learning achievements and awareness through residence energy saving game-based inquiry playing. Journal Computer Education, 2(2), 227-243. https://doi.org/10.1007/s40692-015-0033-2

Vega, L. D. (2014). Effect of an elementary two way bilingual Spanish-English immersion school program on junior high and high school student achievement [PhD thesis, Colorado State University].

Wilfried, A., Jantina, H., Irma, H., Els, K., Monique, V., \& Geert, D. (2014). Gender-inclusive game-based learning in secondary education. International Journal of Inclusive Education, 18(11), 1208-1218. https://doi.org/10.1080/13603116.2014.885592

Wu, T.-T. (2018). Improving the effectiveness of English vocabulary review by integrating ARCS with mobile game-based learning. Journal of Computer Assisted Learning, 34(3), 1-9. https://doi.org/10.1111/jcal.12244

Yang, J. C., \& Chen, S. Y. (2010). Effects of gender differences and spatial abilities within a digital pentominoes game. Computers \& Education, 55(3), 1220-1233. https://doi.org/10.1016/j.compedu.2010.05.019

Yien, J. -M., Hung, C. -M., Hwang, G. -J., \& Lin, Y. -C. (2011). A game-based learning approach to improving students' learning achievements in a nutrition course. The Turkish Online Journal of Educational Technology, 10(2), 1-10.

Yusoff, A. (2010). A conceptual framework for serious games and its validation [Unpublished PhD thesis, University of Southampton].

Zaid Arafat, M. N., Nik Mohd Rahimi, N. Y., Irma Matriny, M. Y., \& Mohd Yusri, K. (2016). Foreign language vocabulary learning strategies in Malaysia. Creative Education, 7, 428-434. https://doi.org/10.4236/ce.2016.73042

Zainur Rijal, A. R., \& Rosni, S. (2018). Saiz kosa kata bahasa Arab dalam kalangan pelajar di peringkat pengajian tinggi: Permasalahan dan strategi pengajaran [Arabic vocabulary size among students in higher education: Problems and teaching strategies]. International Journal of Language Education and Applied Linguistics, 8(2), 61-70. 
Zainur Rijal, A. R., Rosni, S., Mohammad Fauzi, J., \& Mohd Shahriman, A. B. (2016). Kebolehan menguasai kosa kata bahasa Arab dalam buku teks di kalangan pelajar Sijil Tinggi Agama Malaysia (STAM) [Ability to master Arabic vocabulary in textbooks among students of Sijil Tinggi Agama Malaysia (STAM)]. International Journal of Language Education and Applied Linguistics, 5, 33-43.

Correspondence: Mohammad Taufiq Abdul Ghani, Universiti Pendidikan Sultan Idris, Malaysia.

E-mail: taufiq@fbk.upsi.edu.my 